\title{
GIS MODELING FOR MINERAL POTENTIAL MAPPING OF CARBONATE-HOSTED PB-ZN DEPOSITS
}

\author{
WASHINGTON FRANCA-ROCHA ${ }^{1,3}$, GRAEME BONHAM-CARTER ${ }^{2}$, AROLDO MISI ${ }^{3}$
}

\begin{abstract}
Resumo MODELAGEM EM AMBIENTE SIG PARA MAPEAMENTO DA PROSPECTIVIDADE MINERAL EM DEPÓSITOS CARBONÁTICOS DE Pb-Zn Um conjunto de dados de prospecção regional de depósitos carbonáticos de $\mathrm{Pb}-\mathrm{Zn}$ na bacia Neoproterozoica de Irecê (Bahia - Brazil) foi modelado em ambiente SIG (Sistema de Informações Georreferenciadas) com auxílio de recursos quantitativos que executam os métodos Lógica Fuzzy e Probabilidade Bayesiana. Estes depósitos encontram-se em sequências carbonáticas de fácies de águas rasas do Grupo Una-Bambuí e mostram forte controle estratigráfíco com o final do primeiro ciclo transgressivo-regressivo (Unidade B1 da Formação Salitre). Os dados modelados incluem mapas geológicos na escala 1:100.000, levantamentos de aerogamaespectrometria, levantamentos de geoquímica de solo e imagens de satélites LANDSAT TM. Vinte depósitos minerais de sulfeto stratabound de $\mathrm{Pb}-\mathrm{Zn}$ foram empregados no treinamento da base de dados. Vinte mapas de evidências foram derivados dos dados originais a partir de processamento em ambiente SIG, baseados em um modelo exploratório consistindo de cinco fatores: estratigráfico, estrutural, geoquímico, geofísico e fator multiespectral. Cálculos de pesos de evidências $\left(\mathrm{W}^{+}, \mathrm{W}^{-}\right) \mathrm{e}$ contraste $\left(\mathrm{C}=\mathrm{W}^{+}-\mathrm{W}^{-}\right)$guiaram a modelagem baseada nos dados, enquanto o modelo exploratório conduziu a modelagem baseada no conhecimento. $\mathrm{O}$ fator geoquímico foi o que melhor prognosticou os depósitos minerais. Os mapas geofísicos não possuem resolução espacial suficiente para detectar depósitos minerais mas foram de grande ajuda na identificação de variáveis regionais.
\end{abstract}

Palavras-chave: modelagem SIG, mapa da prospectividade mineral, depósitos de $\mathrm{Pb}-\mathrm{Zn}$

\begin{abstract}
Regional exploration datasets from carbonate-hosted $\mathrm{Pb}-\mathrm{Zn}$ deposits in the Neoproterozoic Irecê Basin (Brazil) were modeled by GIS-based (Geographic Information System) predictive, probabilistic tools that allow fuzzy logic and weights-ofevidence methods to be applied. These deposits are hosted within dolomitic shallow-water facies in the carbonate sequences of the Una-Bambui Group, and show remarkable stratigraphic control at the end of the first regressive cycle (the so-called B1 Unit, Salitre Formation). The datasets used for this study include a geological map (1:100.000 scale), airborne radiometric grids, a soil geochemical survey and two LANDSAT TM images. Twenty known stratabound $\mathrm{Pb}-\mathrm{Zn}$ sulfide deposits were employed as training points. Thirteen evidential themes derived by GIS processing based on the exploration model were grouped into five factors: stratigraphic, structural, geochemical, geophysical and multispectral factor. Weights $\left(\mathrm{W}^{+}, \mathrm{W}^{-}\right)$and contrast $\left(\mathrm{C}=\mathrm{W}^{+}-\mathrm{W}^{-}\right)$calculations guided the data-driven modeling, and an exploration model supported the choice of fuzzy membership functions for the knowledge-driven modeling. The most predictive factor was the geochemical factor. The geophysical maps, although not having sufficient spatial resolution to predict deposits, provide important regional screening variables.
\end{abstract}

Keywords: GIS modeling, mineral potential map, $\mathrm{Pb}-\mathrm{Zn}$ deposits

INTRODUCTION Mineral exploration procedures always need to integrate data in order to consider a vast range of combinations and to underline different hypotheses. The analysis of spatially located data is one the basic concerns of exploration geologists, and can be more efficiently executed with assistance of Geographical Information Systems (GIS). One of the major applications of a GIS is the ability to integrate and combine multiple layers of lithology, structure, geophysical and geochemical characteristics to delineate mineral prospectivity maps (Chung and Agterberg 1980, Bonham-Carter et. al. 1988, Harris 1989, Moon et. al. 1991, Agterberg et al 1993, Bonham-Carter 1994, Rencz et. al. 1994, Wright and Bonham-Carter 1996, Harris et. al. 2000, Raines 1999). In this study a GIS-based spatial analysis were applied to build maps showing areas favorable for lead-zinc deposits in the Irecê carbonate basin (NE Brazil).

The lead-zinc deposits and their host Proterozoic sedimentary basins are located in the São Francisco Craton, Brazil, and occur over an area of more than $300.000 \mathrm{~km} 2$. The majority of known deposits are hosted by Neoproterozoic dolomitic units of the Bambui Group and their equivalents, constituting an extensive carbonatic platform that covers the San Francisco craton and extends beyond its borders. Only two of them are currently mined: Vazante, $8 \mathrm{Mt}(23 \% \mathrm{Zn})$ and Morro Agudo, $12 \mathrm{Mt}(6,4 \% \mathrm{Zn}, 2,2 \%$ $\mathrm{Pb})$, respectively producing $650.000 \mathrm{t} / \mathrm{year}(\mathrm{ROM})$ with $13,5 \% \mathrm{Zn}$ and $580.000 \mathrm{t} / \mathrm{year}(\mathrm{ROM})$ with $5 \% \mathrm{Zn}$ and $2 \% \mathrm{~Pb}$. They are hosted by dolostones of the Neoproterozoic Vazante Group, a folded coun-

1 - Universidade Estadual de Feira de Santana, Departamento de Ciências Exatas, Campus Universitário, Km 03, BR-116, CEP 44031-460, Feira de Santana, Bahia, Brazil

2 - Geological Survey of Canada, 601 Booth St., Ottawa, Ontario, K1A 0E9, Canada.

3 - Research Group on Metalogenesis, Centro de Pesquisa em Geofísica e Geologia and Curso de Pós-Graduação em Geologia, Instituto de Geociências, Universidade Federal da Bahia. Rua Caetano Moura, 123 CEP 40210-340, Salvador, Bahia, Brazil.

E-mail: wrocha@uefs.br, bonhamcarter@gsc.nrcan.ca,misi@ufba.br 
terpart of the Bambuí Group in the western border of the São Francisco Craton.

The Irecê Basin is constituted by carbonate sequences of the Una Group located in the central-eastern portion of the São Francisco Craton, Bahia State (Fig. 1). The Irecê Basin is a small triangular-shaped basin composed by the Neoproterozoic Salitre Formation, that comprises at least $1.2 \mathrm{~km}$ thick of predominantly carbonate rocks, lying unconformably over two units: glaciogenic sediments (diamictites) of the Bebedouro Formation, and the Mesoproterozoic siliciclatic metasediments of the Chapada Diamantina Group. Two transgressive-regressive cycles have been identified (units B and B1 - laminated dolomitic limestone and cherty dolomite; and units A and A1 - pelites, marls and black limestone).

Stratabound $\mathrm{Pb}-\mathrm{Zn}$ sulfide deposits are hosted by dolomites in the carbonate sequences. The main characteristic of the Irecê Basin deposits is that they show remarkable stratigraphic control at the top of the first cycle of a shallowing-upward sequence (Misi et al. 1999). They have massive and/or disseminated stratiform, stratabound and vein-type mineralization. Stratabound forms are always related to shallow sedimentary environments (Misi 1999). Outcropping sulfide deposits are weathered meteorically forming Fe-rich crusts (gossans). Figure 2 presents the deposit model of the $\mathrm{Pb}-\mathrm{Zn}$ deposits (Misi 1999) and Figure 3 shows the geologic map of the Irecê Basin, based on previous geological maps (Bonfim et. al. 1985), on processed LANDSAT TM satellite image and on field checks (Franca-Rocha 2001).

The major objective of this study was to integrate geological, geochemical and geophysical data sets to build a mineral potential map for $\mathrm{Pb}-\mathrm{Zn}$ carbonate-hosted deposits. To achieve the objectives, the methods of weights of evidence (Agterberg et al. 1990) and fuzzy logic (An et al. 1991) were applied to characterize the patterns associated with a small number of known deposits and described by the deposit model (Figure 2).

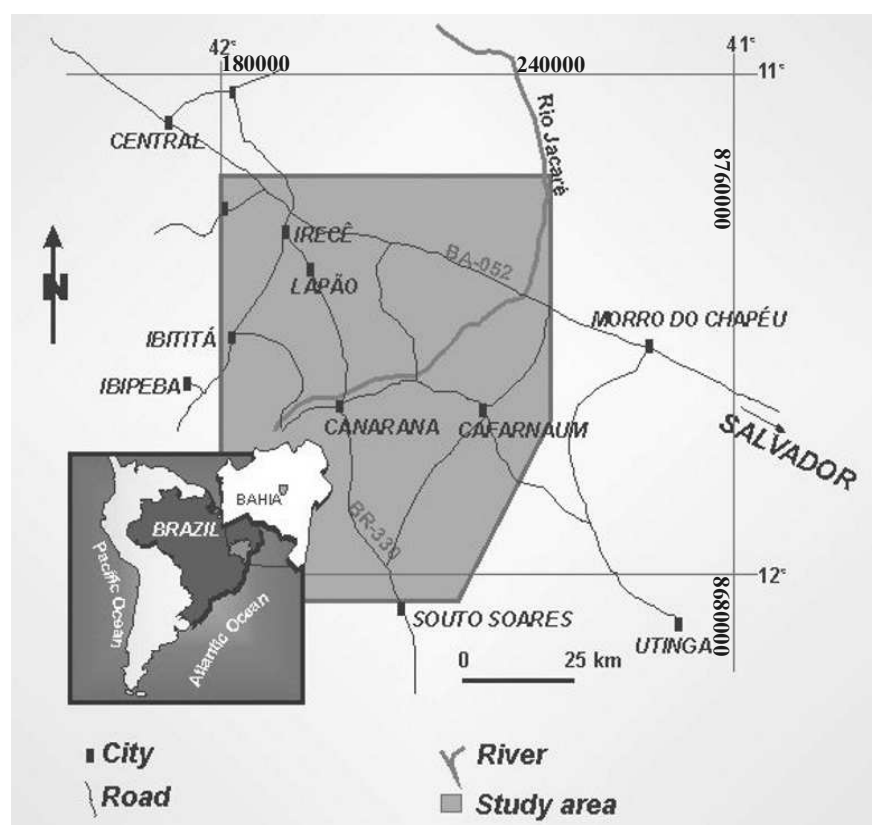

Figure 1 - Geographic location of the study area.
METHOD Overall, the methodology involves conceptual modeling, database building, intermediate-layer generation, data integration and metallogenic interpretation. Here we report on the application of two methods of integrating exploration data sets: fuzzy logic and weights of evidence.

Thirteen themes used as evidence of deposits in this study were derived from the raw data sets, that consisted of a digitized geological map, airborne radiometric and soil geochemical survey data. The uranium and thorium maps are incomplete (i.e. the surveys have gaps, or missing data) and the lead and zinc maps are based on uneven sample density, giving rise to sources of uncertainty in the posterior probability map that can be taken into consideration in modeling. Twenty $\mathrm{Pb}-\mathrm{Zn}$ deposits were used as training points. Table 1 summarizes the original data sets processed in this study.

THEORETICAL BASIS Fuzzy logic method The fuzzy logic approach can be effective as a method to weight and combine spatial evidence when the proposition (such as "this location is favourable for mineral deposits") is vague. Fuzzy logic uses membership functions $(\mu)$ and various different combination operators. Mathematically, a fuzzy set A is a set of ordered pairs:

$$
A=\left\{\left(x, \mu_{A}(x)\right) \mid x \in X\right\} \quad \text { Eq. } 1
$$

where, $\mathrm{X}=$ collection of objects, also known as the universal set and $\mu(x)=$ membership function or degree of compatibility of $x$ in $\mu(\mathrm{x})$ (An et. al. 1991). The range of $\mu(\mathrm{x})$ is $[0,1]$, where 0 represents non-membership and 1 represents full membership. An et al. (1991) discuss five operators that were found to be useful for combining exploration datasets, namely the fuzzy AND, fuzzy OR, fuzzy algebraic product, fuzzy algebraic sum and fuzzy gamma operator. The fuzzy OR, for example, is like the Boolean OR (logical union) in that the output membership values are controlled by the maximum values of any of the input maps, for any particular location. Using this operator, the combined membership values are limited by the most suitable of the evidential map patterns. The OR-operator can be used where two map patterns represent the same level of evidence, and the combinations suggest evidence at higher probability. Gamma operator $(\gamma)$ is a combination of the fuzzy algebraic

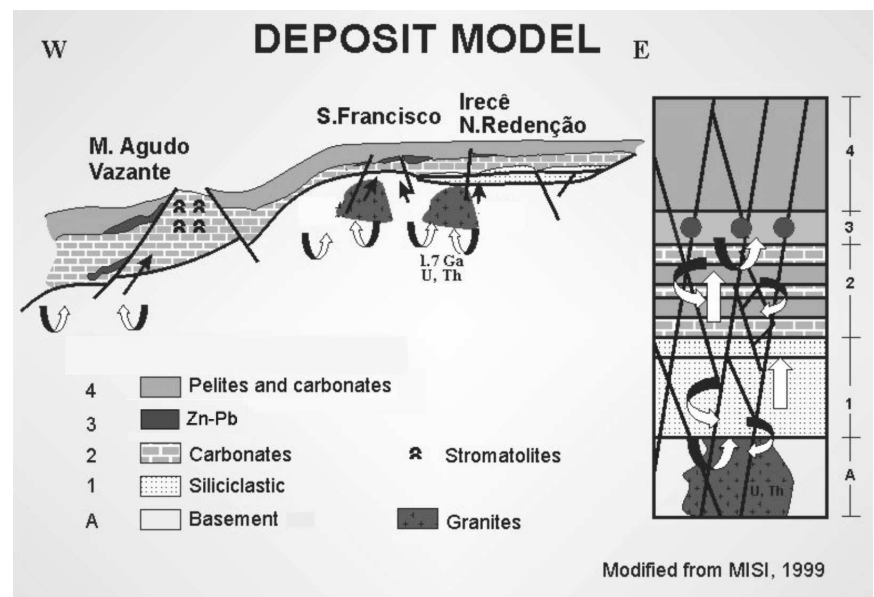

Figure 2 - Carbonate-hosted $\mathrm{Pb}-\mathrm{Zn}$ sulfide deposit model in the São Francisco Craton (modified from Misi 1999). 


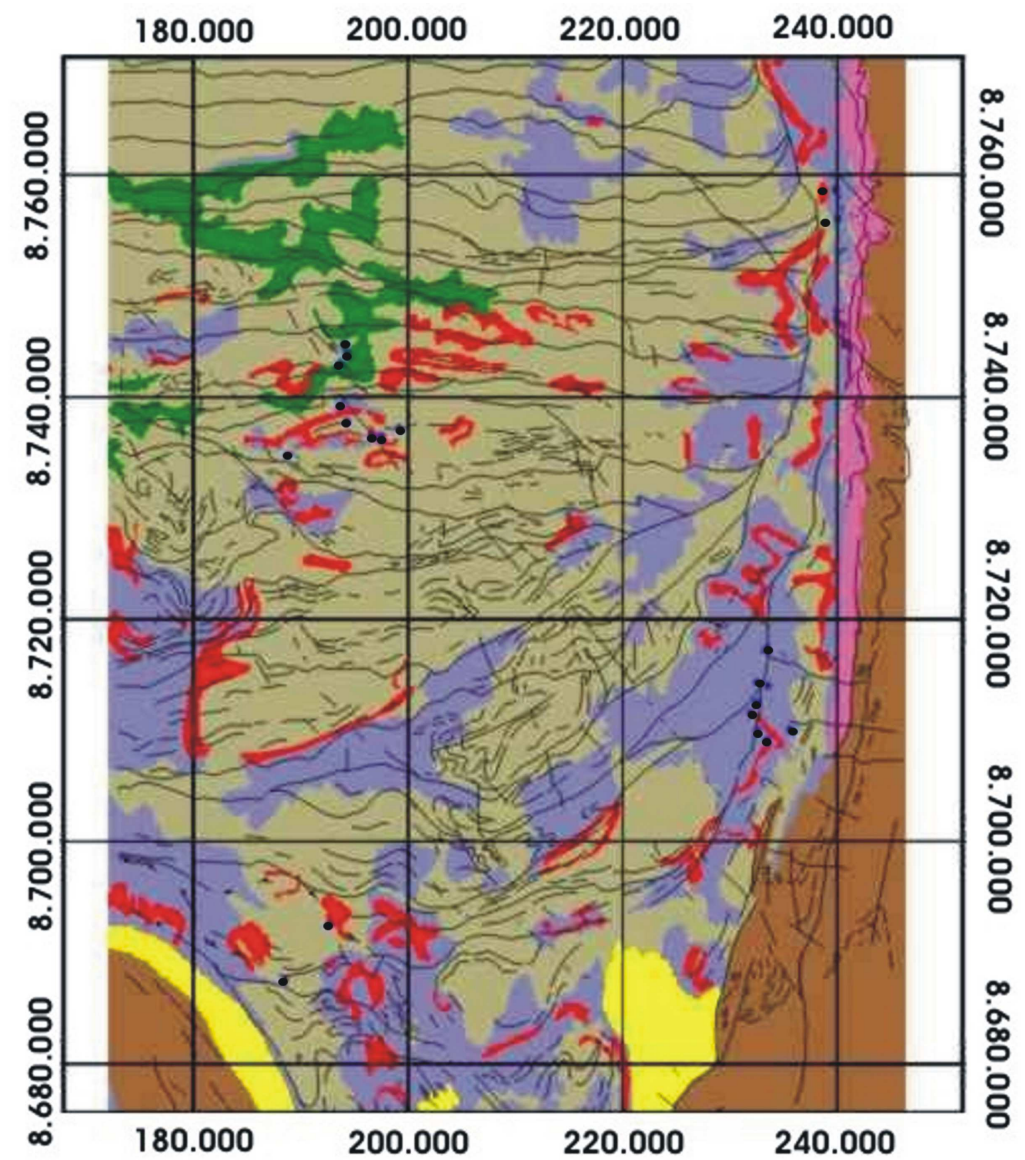

\section{GEOLOGY OF IRECÊ BASIN}


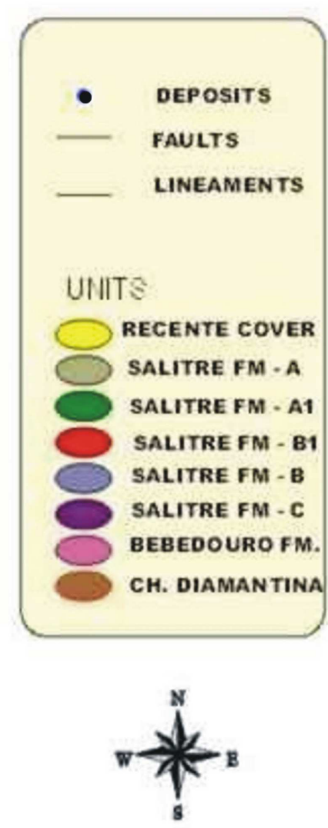

20 0
$20 \mathrm{Km}$

Figure 3 - Geological features of the Irecê Basin. Units B and B1 are the first cycle sequence and Units A and A1 are the second cycle sequence. $\mathrm{Pb}-\mathrm{Zn}$ deposits are related with the first cycle sequence (Franca-Rocha 2001).

Table 1 - Summary of Data Sets Used in the GIS Modeling

\begin{tabular}{|c|c|}
\hline Data type & Description \\
\hline Geology (lithology and structure) & Geological maps at scale 1:100.000 (Bonfim et. al. 1985). \\
\hline $\begin{array}{l}\text { Geochemistry } \\
\text { - soil } \\
\text { - stream sediments } \\
\text { - lithogeochemistry }\end{array}$ & $\begin{array}{l}\text { Regional survey data from CPRM (Geologic Survey of Brazil) } \\
\text { data base. Files are in ASCII format. Follow-up survey data from CBPM } \\
\text { (Companhia Baiana de Pesquisa Mineral) files. Files are also in ASCII format. }\end{array}$ \\
\hline \multirow{2}{*}{$\begin{array}{l}\text { Geophisics } \\
\text { - Gravity (Bouger) } \\
\text { - Airborne magnetics } \\
\text { - Airborne radiometrics (U, Th, K) }\end{array}$} & $\begin{array}{l}\text { CPRM (Geologic Survey of Brazil) data base (Gomes \& Motta 1980). Files } \\
\text { are in ASCII format. }\end{array}$ \\
\hline & $\begin{array}{l}\text { CPRM (Geologic Survey of Brazil) data base (Mourão \& Andrade 1984). } \\
\text { Files are in ASCII format. }\end{array}$ \\
\hline Mineral Deposits & $\begin{array}{l}\text { Compiled from CPRM and CBPM data bases ( (Bonfim et. al. 1985. Souza et } \\
\text { al. 1993). }\end{array}$ \\
\hline Remote sense data (Landsat) & $\begin{array}{l}\text { Landsat TM images, bands } 1-7, \text { WRS } 218 / 68 \text { and WRS } 217 / 68 \text {, respectively } \\
\text { collected on } 27 / 10 / 1995 \text { and } 25 / 08 / 1998 \text {, at } 30 \text { m resolution }\end{array}$ \\
\hline
\end{tabular}

product and the fuzzy algebraic sum, and produces output values that ensure a flexible compromise between the "increasive" tendencies of the fuzzy algebraic sum and the "decreasive" effects of the fuzzy algebraic product.

For a review on the fuzzy operators for combining geological data sets, refer to Bonham-Carter (1994) and An et al. (1991).

Weights of evidence method Weights of evidence (WofE) is a quantitative method that uses a log-linear formulation of Bayes' Rule of Probability with an assumption of conditional indepen- 
dence to combine map patterns. WofE has been used by geologists to identify areas favorable for geologic phenomena, such as mineralization and seismicity. The weights-of-evidence method allows the user to explore the spatial relationship between known mineral deposits and exploration data sets from a variety of sources (Bonham-Carter 1994). In mineral exploration applications, a series of evidence maps (evidential themes) derived from geochemical, geophysical and geological data sets are combined to produce a mineral prospectvity (or potential) map. The spatial association of each evidential theme is assessed with respect to the locations of known deposits, used as training points.

Because most studies of this type only have a limited number of deposits, it is advantageous to generalize the maps to a small number of classes, often to binary classes, because a weight is estimated for each class and these estimates are not robust when the number of training points is small. A pair of weights, $\mathbf{W}^{+}$and $\mathbf{W}^{-}$, determined from the degree of overlap between the known deposits and the binary evidence map (e.g. geochemical anomaly map), is calculated for each map to be used as evidence.

If there is no spatial association between the training points and the binary evidence map, then $\mathbf{W}^{+}=\mathbf{W}^{-}=0$. A positive $\mathbf{W}^{+}$value indicates a positive association between training points and the evidence map. In this case, more of the known deposits occur on the map class than would be expected if the number of deposits occurring there could be explained as due to chance. Conversely, a negative association implies the occurrence of fewer known deposits on that map class than would be expected due to chance.

The contrast value $\mathbf{C}$, where $\mathbf{C}=\mathbf{W}^{+}-\mathbf{W}^{-}$, is a summary value that reflects the degree of spatial association between the evidence map and the mineral prospects. The larger the $\mathbf{C}$ value, the greater is the spatial association. A study of weights and contrast values can facilitate the process of identifying breaks between background and anomalous values in geochemical data, or in identifying critical distances on evidential themes related to proximity to spatial objects (Bonham-Carter 1994, ch. 9).

The process of evaluating weights, contrast and reclassifications gives invaluable insight into the spatial associations present in the data (e.g. separation of background from anomaly in geochemistry, selection of optimal distances for buffering linear features, etc.). The effects of various sources of uncertainty on the final result can be modeled, such as the variances of weights and variance due to missing data (incomplete surveys). A recent development allows the effect of kriging variance on the weights to be modeled (Bonham-Carter \& Agterberg 1999).

The principal disadvantage of weights of evidence is that it assumes conditional independence between the data (evidence maps) (e.g. an elevated concentration in $\mathrm{Pb}$ is independent of an elevated concentration in $\mathrm{Zn}$, conditional on the locations of deposits). This conditional independence assumption is often violated when producing a prospectivity map, although the degree of violation depends on the choice and number of maps used as predictors.

There are various tests for conditional dependence (Agterberg and Cheng 2002), but ultimately the safest way to check the effect of conditional dependence on the results is to carry out a logistic regression analysis on the same input data sets. The response and predictor variables are the same as weights of evidence, except that multistate categorical maps must be recoded to binary form. The coefficients are somewhat similar to the "contrast" in weights of evidence, except that they are solved simultaneously, and allow the predictors to be intercorrelated (Agterberg et al
1993). The patterns of the posterior probability maps between the two methods can be compared. In general, apart from minor differences, the rank order of probability values between the two methods is generally similar, except the scaling can differ. BonhamCarter (1994) provides more detailed discussions of the WofE method and how the weights are calculated.

RESULTS AND DISCUSSION One consideration with the WofE approach, as previously mentioned, is the issue of conditional independence between the evidence maps. The thirteen binary maps were used, at first, to model mineral favorability, but statistical tests showed problems with conditional dependence and a recombination of the maps by factors was applied. Table 2 summarizes the statistics from the WofE, considering twenty $\mathrm{Pb}$ $\mathrm{Zn}$ deposits in the Irecê Basin. Thus, some evidence maps were combined resulting in five factor maps: stratigraphic factor, structural factor, geochemical factor, geophysical factor and multispectral factor. Figure 4 shows the knowledge-driven (fuzzy logic) $\mathrm{Pb}$ $\mathrm{Zn}$ prospectivity map derived from all the data. Figure 5 shows the final integrated mineral potential maps modeled by the data-driven (WofE) method.

Tests of conditional independence were executed considering the five maps of factors. Table 3 shows the calculated chi-square values returned from these tests, suggesting that no serious problem of conditional dependence on a pairwise basis exist. With 1 degree of freedom and at $98 \%$ probability level, the theoretical value of chi-square is 5.4, greater than any value observed in the table, and thus the null hypothesis of conditional independence is rejected at this level. .

The best predictors (Table 2 - see rank by $\mathrm{C}$ column) are

Table 2 - Weights ( $W+, W$-), contrast $(C)$ values and studentized contrast values $(C / s(C))$. Rows are sorted by decreasing $C, a$ measure of spatial association between the deposits and the map. Prior probability is 20/5498.63=0.0036 (assuming unit cell $=1$ $\left.\mathrm{km}^{2}\right)$.

\begin{tabular}{|l|c|c|c|c|}
\hline \multicolumn{1}{|c|}{ FACTORS MAPS } & $\mathrm{W}+$ & $\mathrm{W}-$ & $\mathrm{C}$ & $\mathrm{C} / \mathrm{S}(\mathrm{C})$ \\
\hline Geochemical Factor & 1.7649 & -0.3690 & 2.1339 & 4.5185 \\
\hline Geophysical Factor & 1.3963 & -0.1724 & 1.5686 & 2.7887 \\
\hline Structural Factor & 1.0655 & -0.3625 & 1.4281 & 3.1173 \\
\hline Stratigraphic Factor & 1.0563 & -0.1967 & 1.2530 & 2.4161 \\
\hline TM Factor & 0.4448 & -0.0614 & 0.5063 & 0.8063 \\
\hline
\end{tabular}

Table 3 - Pairwise tests of conditional independence (CI). The tabled value of chi-squared with 1 degree of freedom and probability level of 0.98 is 5.4. Therefore the null hypothesis of CI is not rejected if all calculated chi-squared values are $<5.4$.

\begin{tabular}{|c|c|c|c|c|}
\hline Factors & $\begin{array}{c}\text { Structural } \\
\text { Factor }\end{array}$ & $\begin{array}{c}\text { Geochemical } \\
\text { Factor }\end{array}$ & $\begin{array}{c}\text { Geophysical } \\
\text { Factor }\end{array}$ & $\begin{array}{c}\text { FM } \\
\text { Factor }\end{array}$ \\
\hline Stratigraphic Factor & 2,50 & 0,07 & 0,42 & 0,13 \\
\hline Structural Factor & & 0,08 & 1,05 & 0,15 \\
\hline Geochemical Factor & & & 1,66 & 0,00 \\
\hline Geophysical Factor & & & & 0,39 \\
\hline
\end{tabular}


FUZZY LOGIC MODEL

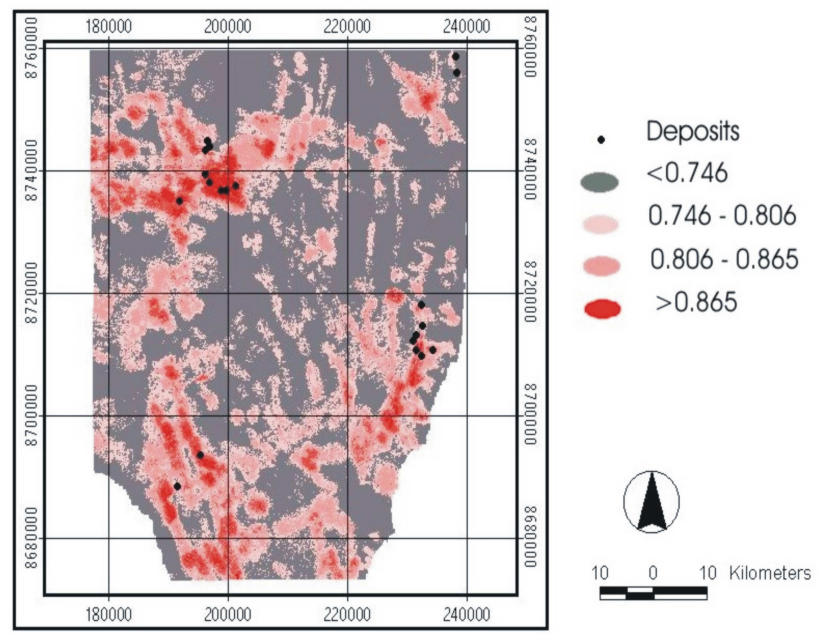

Figure 4 - Mineral favourability map from fuzzy logic modeling

\section{WEIGHTS OF EVIDENCE MODEL}

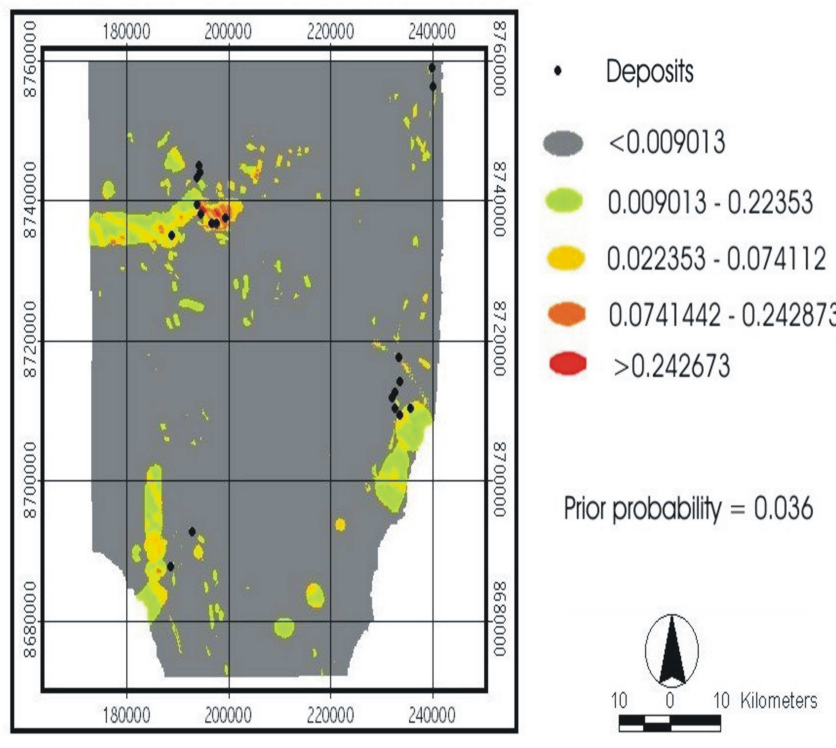

geochemical and geophysical factors, showing the importance of these surveys as techniques for prospecting for deposits of this type. It is interesting to note that geologic structures, especially NW-SE-trend, appear as the third best predictor of the $\mathrm{Pb}-\mathrm{Zn}$ deposits in Irecê Basin, supporting this aspect of the exploration model.

CONCLUSIONS The $\mathrm{Pb}$ and $\mathrm{Zn}$ content of soil, structural lineaments, radiometric uranium, the presence of B and B1 units and the proximity to the contacts of the stratigraphic cycles provide relatively good predictors of the known $\mathrm{Pb}-\mathrm{Zn}$ deposits in the Irecê Basin. Fuzzy logic and weights of evidence map comparison indicates some differences in the patterns (Fig. 6). Despite this, almost all deposits in the basin are predicted satisfactorily (i.e. fall in high probability areas). High probability areas in both models show differences in absolute values, according to the

\section{FUZZY LOGIC X WEIGHTS OF EVIDENCE}

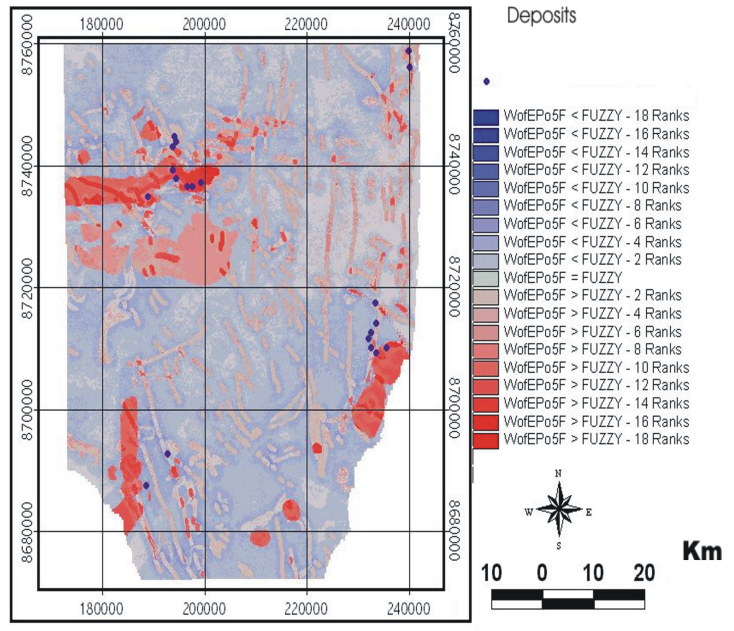

Figure 6 - Map of rank differences comparing results obtained from the weights of evidence and fuzzy logic modeling. Areas where the input maps match are colored gray; the greater the FUZZY ranked data is than the WofE, the greater the saturation of blue; and where the the rank of the WofE value is greater than the FUZZY value, the greater is the saturation of red.

method, but predict the same regions

A drawback in this type of modeling is that it assumes that the points used for training are a homogeneous group. More detailed mapping in that area with support from Landsat, Aster and Radarsat images may be helpful to improve stratigraphic and structural criteria. To-date our GIS study has shown that these maps provide the best evidence for predicting the known deposits. The methods developed here may be applied in other locations within the São Francisco Basin.

Acknowledgements This paper was funded by a grant from $\mathrm{CNPq}$ (Brazilian Council for Scientific and Technological Development) to W. Franca Rocha. To CPRM (Geological Survey of Brazil) and CBPM (Companhia Baiana de Pesquisa Mineral) for the provision of exploratory data used in this modeling. To Geological Survey of Canada (Ottawa Office) for providing facilities for the modeling study. To the referees of RBG for critical review of the manuscript.

\section{References}

An P., Moon W. M., Rencz A. 1991. Application of fuzzy set theory for integration of geological, geophysical and remote sensing data. Can. Jour. Explor. Geoph., 27:1-11.

Agterberg F.P., Bonham-Carter G.F., Wright D.F. 1990 Statistical Pattern Integration for Mineral Exploration. In: G. Gaal \& D.F. Merriam (eds.) Computer Applications in Resource Estimation, Prediction and Assessment for Minerals and Petroleum, Pergamon, Oxford, pp.:121 .

Agterberg F.P., Bonham-Carter G.F., Cheng Q., Wright D.F. 1993. Weights of evidence modeling and weighted logistic regression for mineral 
potential mapping. In: J.C. Davis \& U.C. Herzfeld (eds.) Computers in Geology-25 Years of Progress. Oxford University Press, International Association of Mathematical Geology. Studies in Mathematical Geology 5 pp.: 13-32.

Agterberg, F.P. and Cheng, Q. 2002. Conditional independence test for weights-of-evidence modeling. Nat. Resou. Res., 11:249-255.

Bonfim L.L.C., Rocha A.J.D., Moraes Filho J.C.R., Guimaraes J.T., Tesch N.A., Motta A.C., Souza G.V.V., Barral S.M.Q. 1985. Projeto Bacia de Irecê, SME/SGM/CPRM, 3 vol. (Relatório final).

Bonham-Carter, G.F. 1994. Geographic Information Systems for Geoscientists: Modelling with GIS. New York, Pergamon/Elsevier, 398 p.

Bonham-Carter G.F \& Agterberg F.P. 1999 Arc-WofE: an Arcview Extension for Mineral Potential Mapping by the Weights-of-Evidence Method. In: Inter. Stat. Institute, Proceedings, Helsinki, Aug. p.1118.

Bonham-Carter G.F., Agterberg F.P., Wright D.F. 1988. Integration of geological Data sets for gold exploration in Nova Scotia. Photogr. Engine. Remote Sensing, 54:1585-1592.

Chung C.F. \& Agterberg F.P. 1980. Regression models for estimating mineral resources from geological map data. Math. Geology, 12:473488.

Franca-Rocha W.J.S. 2001 Modelagem metalogenetica na Bacia de Irecê (Ba) através de Sistema de Informações Geográficas (SIG). Tese de Doutoramento, Instituto de Geociências, Universidade Federal da Bahia, Salvador, , $350 \mathrm{p}$.

Gomes R.A.A.D. \& Motta A.C. 1980 Projeto Levantamento Gravimétrico no Estado da Bahia, CPRM, Salvador.

Harris, J. R. 1989. Data integration for gold exploration in eastern Nova Scotia using a GIS. In: Remote Sensing for Exploration Geology, Proc. Calgary, Alberta, p. 233-249.

Harris J.R., Wilkinson L., Grunsky E. C. 2000. Effective use and interpretation of lithogeochemical data in regional exploration programs. Ore Geol. Rev., 16:107- 143.
Misi A., Iyer S.S., Tassinari C.G., Kyle J.R., Coelho C.E.S., FrancaRocha W., Gomes A.S.R, Cunha I.A., Carvalho I.G. 1999. Geological and Isotopic Constraints on the Metallogenic Evolution of the Proterozoic Sediment-Hosted Pb-Zn(Ag) Deposits of Brazil, Gondwana Research, 2:47-65.

Misi A. 1999. Um modelo de evolução metalogenética para os depósitos de Zinco e Chumbo nos sedimentos proterozóicos de coberturas do craton do São Francisco (Bahia e Minas Gerais). Tese para concurso de Professor Titular. Universidade Federal da Bahia. 93 p.

Moon W.M., Chung C.F., An P. 1991. Representation and Integration of geological, geophysical and remote sensing data. Geoinformatics, 2:177-182.

Mourão L.M.F. \& Andrade J.B.F. 1982 Projeto Norte da Chapada Diamantina, relatório final, CPRM/SUREMI, Rio de Janiero.

Raines G.L. 1999. Evaluation of weights of evidence to predict epithermal gold deposits in the Great Basin of the western United States: Natural Resources Research. 8:257-276.

Rencz A.N., Harris J.R., Watson G.P., Murphy B. 1994. Data integration for mineral exploration in the Antigonish Highlands, NovaScotia. Can. Jour. Remote Sensing. 20:258-267.

Souza S.L., Brito P.C.R., Silva R.W.S. 1993. Estratigrafia, sedimentologia e recursos minerais da Formação Salitre na Bacia de Irecê, Bahia., Série Arquivos Abertos nº 2., CBPM. Salvador. 36 pp.

Wright D.F. \& Bonham-Carter G.F. 1996 VHMS favourability mapping with GIS-based integration models, Chisel Lake-Anderson Lake Area. In: G.F. Bonham-Carter, A.G. Galley, G.E.M. Hall (eds.) EXTECH I: A Multidisciplinary Ap-proach to Massive Sulphide Research in the Rusty Lake-Snow Lake Greenstone Belts, Manitoba. Geol. Survey Canada Bull. 426, pp.: 339-376.

Manuscrito SR-25

Recebido em 23 de novembro de 2002

Revisão dos autores em 06 de março de 2003 Revisão aceita em 20 de abril de 2003 